\title{
Objek Wisata Pantai Lemo-Lemo di Kabupaten Bulukumba 2000-2015
}

\author{
Anang Agustina, Muhammad Saleh Madjid, dan Jumadi \\ Pendidikan Sejarah FIS UNM \\ Anankat080895@gmail.com
}

\begin{abstract}
Abstrak
Penenlitian dan penulisan ini bertujuan untuk memberikan gambaran Untuk mengetahui latar belakang keberadaan awal Objek Wisata Pantai Lemo-Lemo di Kabupatan Bulukumba, proses perkembangan Objek Wisata Pantai Lemo-Lemo dan dampak keberadaan Objek Wisata Pantai Lemo-Lemo di Kabupatan Bulukumba bagi masyarakat sekitar maupun bagi pemerintah kabupaten bulukumba. Penelitian ini adalah penelitian sejarah dengan pendekatan deskriptif kualitatif, sehingga dalam proses penelitiannya menggunakan metode penelitian yang sesuai dengan kaidah keilmuan sejarah yang terdiri atas beberapa tahapan. Tahapan tersebut adalah heuristik, kritik, interpretasi, dan historiografi. Hasil penelitian ini menunjukkan bahwa Kabupaten Bulukumba memiliki pontensi pariwisata yang dapat dikembangkan secara maksimum oleh pemerintah, sehingga objek wisata pantai lemo-lemo resmi dijadikan sebagai objek wisata yang ada di Kecamatan Bonto Bahari sejak tahun 2000 oleh pemerintah dinas pariwisata Kabupaten Bulukumba. Keberadaan objek wisata pantai lemo-lemo memberikan dampak bagi kehidupan perekonomian, baik bagi masyatakat sekitar pada khususnya dan kabupaten bulukumba pada umumnya.
\end{abstract}

\section{Kata Kunci : Objek Wisata, Pantai Lemo-Lemo}

\begin{abstract}
This research is intended to give an overview To know the background of early existence of LemoLemo Beach Objects in Bulukumba, the development of Lemo-Lemo Coastal Tourism Object in Bulukumba District, and the impact of Lemo-Lemo Beach Object in Bulukumba District around and for the district government bulukumba. This study is a historical research with qualitative descriptive approach, so that in the process of research using research methods in accordance with historical scientific rules consisting of several stages. The stages are heuristics, criticism, interpretation, and historiography. The results of this study indicate that Bulukumba Regency has tourism potency which can be developed maximally by the government, so that the tourist object of lemo-lemo beach is officially used as tourism object in Bonto Bahari Subdistrict since 2000 by Bulukumba Regency Tourism Office. The existence of lemo-lemo beach attraction gives an impact to the life of the economy, both for the surrounding community in particular and bulukumba district in general.
\end{abstract}

Keywords : Object Tours, Lemo-Lemo Beach 


\section{A. Pendahuluan}

Salah satu sektor kegiatan yang turut mendukung pembangunan nasional adalah sektor pariwisata, Kedudukannya sebagai salah satu sektor pembangunan nasioanal, pariwisata senentiasa diupayakan pengelolaan dan pengembangan sehingga dapat dimanfaatkan secara optimal. Pengembangan kepariwisataan dan kebudayaan di Kabupaten Bulukumba memiliki arti yang sangat penting dan strategis, karena sektor ini merupakan sektor andalan yang nantinya diharapkan mampu mendukung perkembangan pembangunan daerah dengan cara usaha ekonomi daerah multi sektor, serta pemberdayaan dan peningkatan kesejahteraan masyarakat. Memperluas lapangan pekerjaan dan memberikan kontribusi bagi pendapatan daerah.Untuk menciptakan kondisi obyek dan daya tarik wisata ideal yang mampu melayani berbagai kepentingan, antara lain: masyarakat, swasta dan pemerintah, diperlukan usaha penataan dan peningkatan secara optimal sesuai dengan daya dukung dan daya tarik wisatawan. Diharapkan sekaligus dapat merubah dan meningkatkan citra daerah menjadi tujuan wisata yang "pesona tanpa batas". Bonto Bahari salah satu kecamatan yang memiliki potensi tertinggi untuk mengembangkan wisata bahari.Sejauh ini jika berbicara tentang Bulukumba, maka hal yang terbayang adalah perahu pinisi dan Pantai Pasir Putih Tanjung Bira. Dua hal tersebut memang sudah menjadi trade mark bagi kabupaten yang berjulukan Butta Panrita Lopi ini. Pantai Pasir Putih Tanjung Bira memang sudah makmur sebagai destinasi wisata bahari bukan hanya di kancah lokal maupun nasional, tetapi juga di kancah internasional.Demikian pula dengan Pinisi, perahu dengan tujuh layar ini bukan hanya sebagai ikon pariwisata melainkan sebuah warisan leluhur dari budaya bahari nenek moyang.
Lokasi Pantai Lemo-Lemo secara administratif terletak di Kelurahan Tanah Lemo Kecamatan Bontobahari.Lokasi ini berjarak sekitar 33 kilometer dari pusat Kota Bulukumba(BPS, 2015).Daya pikat pantai ini bukan hanya terletak pada pasir putih dan air laut yang masih jernih, tetapi juga beberapa gugusan batu karang yang menyembul ke permukaan air yang masih alami. Fenomena alam unik yang juga di jumpai di Lemo-Lemo adalah tanah berwarna merah yang berdiameter beberapa puluh centimeter saja, Fenomena lain yang menarik di Lemo-Lemo adalah munculnya mata air tawar di pantai, dalam beberapa puluh meter dari pantai terdapat Goa, dengan mata air segar danbersih.

Perbedaan penelitian ini dengan Skripsi yang ditulis oleh Jamaluddin pada tahun 2015 dengan judulObjek Pariwisata Mattampa 3013-2014, Skiripsi ini berfokus pada pariwisata mattampa merupakan Wisata wahana Water Boom yang dengan meliputi perkembangan sarana dan prasarana serta bagaimana dampak yang ditimbulkan bagi masyarakat sekitar terhadap keberadaan wahana Water Boom di Pangkep (Jamaluddin, 2015). Skripsi yang ditulis oleh Syukur pada tahun 2007 dengan judul Objek Wisata Alam Lejja Dikabupaten Soppeng (1991-2002) Skiripsi ini berfokus pada perkembangan wisata alam yang terdapat permandian air panas diDikabupaten Soppeng(Syukur, 2007).Sedangkan pada penelitian ini berfokus pada objek wisata bahari yakni wisata pantai lemo-lemo yang terdapat juga situs bersejarah berupa makam raja-raja, sisa-sisa benteng kerajaan, juga terdapat goa peninggalan dari kerajaan tanah lemo.Untuk selanjutnya peneliti mencoba mengunggapkan bagaimana sejarah, perkembangan dan dampak terhadap keberadaan objek wisata pantai lemo-lemo yang merupakan objek wisata bahari tersebut. 


\section{B. Metode Penelitian}

Metode penelitian yang digunakan ialah kualitatif.Metode ini sering digunakan dalam ilmu sejarah dan ilmu sosial lainnya dengan tujuan untuk menemukan suatu hal yang unik dan mampu mengungkapkan peristiwa yang telah terjadi di masa lampau.Dalam suatu penulisan karya ilmiah, terdapat cara yang digunakan untuk menyusun karya ilmiah tersebut. Hal ini sering disebut sebagai metode. Metode berbeda dengan metodologi. Menurut Kenneth D. Bailey, metode adalah teknik penelitian atau alat yang dipergunakan untuk mengumpulkan data. 1) Heuristik merupakan langkah awal dari metode penelitian sejarah, dimana pada tahap ini seorang peneliti mencari dan mengupayakan penemuan atas sumber sejarah yang memilki keterkaitan dengan objek penelitian. (Sjamsuddin, 2012). 2) Kritik sumber Dalam kritik sumber, terdapat penekanan tertentu yang bertujuan untuk memberikan definisi kritik sumber itu sendiri. Tujuan dari kegiatan-kegiatan ini adalah bahwa setelah peneliti berhasil mengumpulkan sumbersumber dalam penelitiannya, peneliti tidak akan menerima begitu saja apa yang tercantum dan tertulis pada sumber-sumber itu. Selanjutnya peneliti harus menyaringnya secara kritis agar terjaring fakta yang menjadi pilihannya.Langkah-langkah inilah yang disebut kritik sumber, baik terhadap bahan materi (ekstern) maupun terhadap subtansi (isi) sumber. (Sjamsuddin, 2012). 3). Interpretasi merupakan tahapan sumber atau data sejarah yang telah diseleksi dapat digunakan sebagai sumber atau bahan penulisan sejarah, namun sumber tersebut masih harus dilakukan penelitian lebih lanjut. 4) Historiografi adalah Tahap ini merupakan tahap terakhir dalam penelitian sejarah. Pada tahap ini peneliti akan menuliskan peristiwa sejarah tersebut dalam sebuah tulisan yang dalam penulisan, pemaparan dan pelaporan menggunakan tata cara tertentu. Dimana dalam hal ini, penelitian yang dilakukan adalah penelitian dengan kajian kepustakaan dan lapangan (Sulasman, 2010).

\section{Tinjauan Penelitian}

Bonto Bahari adalah sebuah kecamatan di Kabupaten Bulukumba, Sulawesi Selatan, Indonesia. Secara administrasi Kecamatan Bontobahari berbatasan dengan

1. Sebelah Utara : dengan Ujung Loe

2. Sebelah Selatan : dengan Desa Bira

3. Sebelah Timur : dengan Tanah

4. Berubelah Barat : derbatasan Laut Flores

Secara geografis Letak astronomis Kecamatan Bonto Bahari antara 120 22' 30" Bujur Timur dan $5^{\circ} 32$ ' 30" Lintang Selatan dengan sebagian besar berada pada ketinggian 0-500 mdpl. Bonto Bahari terdiri dari empat desa dan empat kelurahan, Tujuh dari delapan desa/kelurahan yang berada di Kecamatan Bonto Bahari merupakan daerah pesisir, Luas wilayah Kecamatan Bonto Bahari adalah $108 \mathrm{~km} 2$, Desa Bira merupakan Desa yang mempunyai wilayah paling luas yaitu 19,5 km2 sedangkan yang mempunyai wilayah yang paling sedikit adalah Kelurahan Tanah Beru yang sekaligus merupakan Ibu Kota dari Kecamatan Bonto Bahari.

Jumlah penduduk Kecamatan Bonto Bahari pada tahun 2015 sebanyak 25.040 jiwa yang terdiri dari 11.382 penduduk lakilaki, dan 13.658 penduduk perempuan. Dengan luas wilayah sekitar 108,60 km2, setiap km2. daerah digunakan sebagai lahan peternakan, Jumlah ternak pada tahun 2015 di Kecamatan Bonto Bahari didominasi oleh ternak kambing. Tercatat ada sebanyak 448 ekor kambing yang dibudidayakan di Kecamatan Bonto Bahari tepatnya terbanyak di Kelurahan Tanah Lemo atau meningkat sebanyak 21 ekor

Masyarakat Kecamatan Bonto Bahari termasuk yang bermukim di kawasan kelurahan tanah lemo menganut agama Islam, seperti yang nampak pada Kartu 
JURNAL PATTINGALLOANG

(C)Jurusan Pendidikan Sejarah Fakultas Ilmu Sosial Universitas Negeri Makassar

Tanda Pengenal (KTP), Mayoritas penduduk Kecamatan Bonto Bahari beragama Islam, yaitu sebesar 99\% dari total jumlah penduduk di kecamatan ini.

D. Pembahasan

1. Latar Belakang Pantai Lemo-Lemo Menjadi Objek Wisata Di Kabupaten Bulukumba

Keberadaan Objek Wisata Pantai LemoLemo ini sangat memberi peluang dan kesempatan kepada pemerintah baik dalam skala lokal, nasional bahkan internasional untuk ikut merencanakan bentuk pengembangan ang diinginkan oleh pemerintahan Kabupaten Bulukumba. Akan tetapi terlepas dari hal tersebut, keberadaan Objek Wisata Pantai Lemo-Lemo banyak dipengaruhi oleh beberapa faktor:

a. Dinas Pariwisata

Dinas daerah mempunyai tugas dan fungsi memberikan pelayanan kepada masyarakat tanpa batas-batas tertentu dapat digunakan sebagai organisasi ekonomi yang memberikan pelayanan jasa dan menghasilkan imbalan (Kaho, 1997). Dinas Pariwisata Kabupaten Bulukumba memiliki Visi dan Misi. Visi : Masyarakat Bulukumba yang Sejahtera dan Terdepan Melalui Optimalisasi Potensi Daerah dengan Penguatan Ekonomi Kerakyatan yang Dilandasi pada Pemerintahan yang Demokratis dan Religius, sedangkan Misi: Penuntasan pelayanan hak dasar masyarakat dibidang infrastruktur, kesehatan, kependudukan dan pendidikan yang merata dan berkeadilan, dan Mendorong peningkatan pendapatan masyarakat melalui percepatan usaha agribisnis dan agroindustri yang berdaya saing dan berbasis kerakyatan dengan menjaga keseimbangan sumber daya alam (bulukumba, 2015).

Keberadaan unit ini difungsikan khusus menangani dan mengelolah serta memilihara sarana dan prasarana yang berada dalam lokasi dimana objek wisata ini berada, termasuk memberikan pelayanan terbaik kepada pengunjung atau wisatawan yang datang.

\section{b. Biro Perjalanan}

Berkembangnya industri pariwisata, maka bermunculanlah biro perjalanan wisata untuk menunjang kegiatan kepariwisataan. Berdasarkan Surat Keputusan Direktur Jenderal Pariwisata No.Kep. 16/U/II/88 tanggal 25 Februari 1988 tentang pelaksanaa ketentuan usaha perjalanan, disebutkan bahwa biro perjalanan wisata adalah kegiatan usaha yang bersifat komersil yang mengatur, menyediakan dan menyelenggarakan pelayanan bagi seseorang, sekelompok orang, untuk melakukan perjalanan dengan tujuan utama untuk berwisata (Andi, 2016 ).

\section{c. Daya Tarik Objek Wisata}

Obyek dan daya tarik wisata sangat erat hubungannya dengan travel motivation dan travel fashion, karena wisatawan ingin mengunjungi serta mendapatkan suatu pengalaman tertentu dalam kunjungannya. Daya tarik yang tidak atau belum dikembangkan semata-mata hanya merupakan sumber daya potensial dan belum dapat disebut daya tarik wisata, sampai adanya suatu jenis pengembangan tertentu, misalnya penyediaan aksesibilitas atau fasilitas(Pendit, Ilmu Pariwisata sebuah pengantar perdata, 1986)

Pantai Lemo-lemo sangat potensial di jadikan tempat wisata kelas menengah keatas.Berbagai daya tarik dapat dilihat disini, selain keindahan pantainya, objek wisata pantai lemo-lemo pengunjung dapat merasakan kesejukan udara hutan lindung dan kicau burung yang merdu serta atraksi monyet melompat dari pohon yang satu ke pohon yang lainnya.

\section{Awal pantai Lemo-Lemo Menjadi Objek Wisata di Kelurahan Tanah Lemo}

Pantai Lemo-Lemo merupakan salah satu yang berada di Kecamatan Bonto Bahari, Kabupaten Bulukumba, yang terletak di ujung selatan pulau Sulawesi. Keindahan dan kekokohan perahunya dalam menghadapi 
keganasan ombak lautan, telah melahirkan cerita-cerita kepahlawanan yang mengagumkan.Karena kepaiawaian masyarakatnya dibidang bahari hingga Bonto Bahari Bulukumba dijuluki sebagai "Butta Panrita Lopi”, salah satunya kelurahan tanah lemo merupakan tempat pembuatan perahu.

a. Sejarah Singkat Pantai Lemo- Lemo

Lemo-lemo terletak di Kampung Seribu Makam, Kelurahan Tanah Lemo, Kecamatan Bontobahari merupakan pusat kerajaan lemolemo.Kerajaan ini adalah kerajaan yang berada di bawah kekuasaan Kerajaan Gowa.Sebagai sebuah daerah taklukan, Lemolemo berkewajiban untuk menyediakan armada bagi Kerajaan Gowa(Gunawan, 2018)

Oleh karena itu tidak mengherankan jika masyarakat Lemo-Lemo secara turun temurun mewarisi keahlian membuat perahu hingga kini, Meski intensitasnya tidak sebanyak pembuatan perahu di Tanah Beru, tetapi pemandangan pembuatan perahu atau kapal pun masih dapat dijumpai di Lemo-Lemo

\section{b. Peninggalan kerajaan lemo-lemo sebagai situs bersejarah \\ 1) Benteng}

Kelurahan Tanah Lemo terdapat sisa benteng peninggalan Kerajaan Lemo, Struktur bangunan benteng ini, pada susunan paling bawah terdiri dari batu karang yang cukup besar, Selain itu letak benteng yang jaraknya hanya kurang dari satu kilometer dari bibir pantai benteng ini sudah ditumbuhi rumputrumput yang mengelilingi benteng tersebut. Batutidak diketahui angka tahunnya.

\section{2) Meriam dan ranjau laut}

Meriam dan ranjau laut peninggalan kerajaan lemo-lemo yang diletakkan di mesjid yang kemudian dipindahkan ke halaman rumah penduduk. Meriam dimemiliki panjang 1,5 meter, mariam ini sudah berkarat berwarna kehitam-hitaman kerena diterpa hujan dan sinar matahari, sedangkan disampang meriam juga terdapat sebuah bola besi yang diameternya setengah meter dengan tonjolan besi keluar yang menyerupai babi laut dengan kulit hitam, namun bola besi yang berkemungkinan ranjau laut yang biasa digunakan untuk menghalau kapal selam, jengkal permukaaan ranjau ini berlubang dan warnanya pun sudah berkarat, ini menenjukkan bahwa meriam dan ranjau laut peninggalan kerajaan lemo-lemo terabaikan oleh pemerintah maupun mastarakat setempat.

\section{3) Makam Raja-Raja Lemo}

Dijuluki Kampung Seribu Makam sebab di perkampungan tersebut terdapat banyak makam kuno dengan nisan dari batu panjang. Puluhan bukti makam para Raja Lemo-Lemo menjadi bukti bahwa di tempai ini dulunya pernah berdiri sebuah kerajaan yang memegang peranan penting dalam sejarah kemaritiman Nusantara. Makam para pembesar Kerajaan Lemo-Lemo yang terdapat di antara semak-semak hutan di tepian Pantai Lemo-Lemo, salah satu makam yang terletak dalam goa menurut penuturan warga setempat merupakan makam Kareang Loheta yang terkenal dengan kegagahannya yang tak pernah mundur dalam medan perang, ini juga merupakan aset budaya sekaligus wisata yang pantas dikembangkan (Antang, 2018).

\section{4) Goa Lemo-Lemo}

Gua adalah sebuah lubang alami di tanah yang cukup besar dan dalam. Beberapa ilmuwan menjelaskan bahwa dia harus cukup besar sehingga beberapa bagian di dalamnya tidak menerima cahaya matahari; namun dalam penggunaan umumnya pengertiannya cukup luas, termasuk perlindungan batu, gua laut

Gua Lemo-lemo yang terletak bersebelahan dengan pantai, Fenomena alam yang menarik di gua tersebut memiliki sumber air tawar yang begitu jernih, Gua berair jernih.

\section{5) Perkembangan Pengunjung Objek Wisata Pantai Lemo-Lemo Dikabupaten Bulukumba.}




\section{a. Perkembangan Sarana dan Prasarana Objek Wisata Pantai Lemo-Lemo}

Dalam pembangunan prasarana pariwisata pemerintah lebih dominan karena pemerintah dapat mengambil manfaat ganda dari pembangunan tersebut, seperti untuk meningkatkan arus informasi, arus lalu lintas ekonomi, arus mobilitas manusia antara daerah dan sebagainya, yang tentu saja meningkatkan kesempatan berusaha dan bekerja sama. Secara fisik wisata pantai memiliki karakteristik struktur tanah yang stabil, mempunyai kemiringan tanah yang memungkinkan dibangun tanpa memberikan dampak negatif terhadap kelestarian lingkungan, mempunyai daya tarik flora dan fauna, pasir putih dan halus dan terumbu karang dan harus bebas bau tidak enak, asap, debu, serta air tercemar.

Adapun jenis prasarana wisata pantai berupa jalan, listrik, air bersih dan telekomunikasi. Dengan pertimbangan mempunyai nilai pencapaian dan kemudahan berhubungan yang tinggi dan mudah dicapai dengan kendaraan bermotor, memperhatikan resiko bahaya dan bencana serta perancangan sempadan yang memperhatikan tinggi gelombang laut.Dalam hubungannya dengan jenis dan mutu pelayanan sarana wisata di daerah tujuan wisata telah disusun suatu standar wisata yang baik secara nasional maupun secara internasional, sehingga menyediakan sarana wisata tinggal memilih atau menentukan jenis dan kualitas yang akan disediakan. Untuk menunjang kegiatan wisata pantai tentunya membutuhkan sarana pariwisata, adapun sarana wisata bahari berupa: hotel/penginapan, rumah makan, kantor pengelola, tempat rekreasi \& hiburan, WC umum dan Mushallah. Terkait dengan hal tersebut, tabel dibawah ini menggambarkan fasilitas yang dimiliki oleh Objek Wisata Pantai Lemo-Lemo(Bahrun, 2018).

Pengembangan pariwisata perlu diperhatikan sarana dan prasarananya karena sarana dan prasana mempengaruhi kualitas obyek dan respon wisatawan dalam hal kunjungan wisata. Pengembangan pariwisata merupakan bagian dari pembangunan wilayah, maka daerah yang berpotensi sebagai Daerah Tujuan Wisata (DTW) apabila dikembangkan nantinya akan membantu perekonomian daerah tersebut. Kegiatan pariwisata tidak akan berjalan lancar tanpa adanya peran pendukung, seperti layanan transportasi, layanan jasa makanan dan minuman dan lain sebagainya. Layanan-layanan tersebut menjadikan wisatawan tidak akan kesulitan memperoleh kebutuhan pariwisata.

\section{b. Perkembangan wisatawan Objek Wisata Pantai Lemo-Lemo}

Pengelolah Objek Wisata Pantai LemoLemo menyediakan beberapa fasilitas pendukung berbagai aktivitas wisata antara lain musholah, penginapan, WC umum, penyewaan ban, tempat parkir kendaraan, tempat sampah, balai-balai bambu untuk beristirahat, dan warung untuk memanjakan pengunjungnya, Untuk masuk ke objek wisata ini, wisatawan hanya membayar tiket masuk, seharga $\mathrm{Rp} 15.000$ untuk orang dewasa sedangkan bagi anak-anak seharga Rp. 10.000 sampai Rp 5000, untuk menggunakan fasilitas yang ada, dikenakan biaya, seperti: jika pengunjung ingin menggunakan fasilitas balaibalai bambu, ini dikenakan tarif Rp.20.000/Balai. Selain itu, untuk menggunakan fasilitas wc umum, dikenakan tarif Rp.2.000/orang. Jika ingin bermalam di Pantai Lemo-Lemo, pengunjung dapat menyewa penginapan yang terdapat di pinggir pantai dengan biaya sebesar Rp. 300.000 Rp. 500.000/malam.Untuk pengunjung yang ingin berenang di pantai, dapat menyewa ban yang disediakan oleh pengelola pantai dengan biaya sebesar Rp. 5.000/ban (Indriwati, 2018).

Berikut adalah jumlah pengunjung ke Objek Wisata Pantai Lemo-Lemo di Kelurahan Tanah Lemo, Kecamatan Bonto Bahari, Kabupaten Bulukumba lima pada tahun 2004 terakhir :pengunjung objek wisata 
bahari khususnya Objek Wisata Pantai LemoLemo hampir tiap tahun mengalami peningkatan baik dari pengunjung masyrakat setempat maupun dari masyarakat luar dari Kabupaten Bulukumba, pada tahun 2004 tabel menunjukkan bahwa jumlah pengunjung yang berkunjung ke Objek Wisata Pantai Lemo-Lemo sebanyak 11.502 orang.

Pada tahun 2005 dan tahun 2006 jumlah pengunjung yang berkunjung ke Objek Wisata Pantai Lemo-Lemo sebanyak 12.034 (2005) orang dan 12.931 (2006) orang. , pada tahun 2008 tabel menunjukkan bahwa jumlah pengunjung yang berkunjung ke Objek Wisata Pantai Lemo-Lemo sebanyak 15.257 orang.Pengunjung yang berkunjung ke Objek Wisata Pantai Lemo-Lemo ratarata berasal dari bonto tiro, ujung loe, arah dan tanah beru. Pada tahun 2010 objek wisata pantai lemo-lemo telah banyak mengalami perubahan dari segi fasilitas-fasilitas yang memandai sehingga mengakibatkan jumlah pengunjung mengalami peningkatan. Berikut adalah jumlah pengunjung ke Objek Wisata Pantai Lemo-Lemo di Kelurahan Tanah Lemo, Kecamatan Bonto Bahari, Kabupaten Bulukumba lima pada tahun 2010 terakhir :jumlah pengunjung yang berkunjung ke objek wisata pantai lemo-lemo mengalami dinamika jumlah kunjungan. Pada tahun 2010 tabel menunjukkan bahwa jumlah pengunjung sebanyak 18.502 orang dengan pemasukkan sebesar Rp. 95.020.000(Saleng, 2018).

Pada tahun 2011 menunjukkan bahwa jumlah pengunjung yang berkunjung ke Objek Wisata Pantai Lemo-Lemo mengalami peningkatan, jumlah pengunjung yang berkunjung sebanyak 20.420 orang dengan pemasukan sebesar Rp. 114.200.000. Pada tahun 2012 tabel menunjukkan bahwa jumlah pengunjung yang berkunjung ke opbjek wisata pantai lemo-lemo mengalami peningkatan pengunjung yang cukup banyak dengan jumlah pengunjung 22.190 orang dengan pemasukan devisa ke pemerintah sebesar Rp. 250.000.000. pada tahun 2013 dan 2014 mengalami penurunan pengunjung objek wisata pantai lemo-lemo dengan jumlah 21.050 orang dari tahun 2013. Hal ini menunjukkan penurunun yang sangat draktis disebabkan oleh rasa jenuh dari para pengunjung yang berkunjung ke objek wisata pantai lemo-lemo sedangkan jumlah kunjungan di tahun 2014 sebanyak 18.207 dengan pemasukan devisa sebesar Rp. 170.000.000 sampai Rp. 1000.000.000, sehingga pada tahun 2015 terjadi penurunan kunjungan yang cukup draktis dengan jumlah pengunjung 15.460 orang, maka jumlah devis pemerintah sebesar Rp. 75.000.000. Hal demikian disebakan oleh tingkat kejenuhan dari pengunjung dan disebakan adanya tempat wisata bahari yang baru, Menurut Muh Ali Saleng, SH, M.Si selaku kepala Dinas Pariwisata Kabupaten Bulukumba menyatakan bahwa penurunan yang terjadi saat itu dikarenakan Kabupaten Bulukumba, banyak bermunculanan berbagai objek wisata misanya Obyek Wisata Alam, Agro Wisata, Obyek Wisata Budaya dan Sejarah, Obyek Wisata Gunung, Sungai, Gua dan Danau. Sehingga banyak sebagian pengunjung lain memilih tempat wisata baru.

\section{c. Kebijakan Pemerintah dalam Promosikan dan Memperkenalkan Objek Wisata Pantai Lemo-Lemo \\ 1) Strategi Pengembangan Objek Wisata Pantai Lemo-Lemo}

Strategi secara umum adalah proses penentuan rencana para pemimpin puncak yang berfokus pada tujuan jangka panjang organisasi, disertai penyusunan suatu cara atau upaya bagaimana agar tujuan tersebut dapat dicapai. Sedangkan secara khusus, strategi merupakan tindakan yang bersifat incremental (senantiasa meningkat) dan terus-menerus, serta dilakukan berdasarkan sudut pandang tentang apa yang diharapkan oleh para pelanggan di masa depan (Bagus, 2016).

\section{2) Promosi Pengembangan Objek Wisata Pantai Lemo-Lemo}


Promosi atau yang juga dikenal dengan komunikasi pemasaran (marketing communications) adalah berbagai cara untuk menginformasikan, membujuk dan mengingatkan konsumen - secara langsung maupun tidak langsung - tentang suatu produk atau brand yang dijual.Pemasaran pariwisata harus mempertimbangkan berbagai media dan cara baru untuk berkomunikasi dengan wisatawan. Dalam kebijakan pemerintah dalam promosikan dan memperkenalkan Objek Wisata Pantai LemoLemo Berbagai model tersedia dalam bauran komunikasi pemasaran untuk memperkenalkan pada masyarakat luar:

a) Periklanan yaitu segala bentuk presentasi dan promosi non personal yang dibayar tentang ide, barang, jasa, atau tempat oleh pemasang iklan (perusahaan, pemerintahan, organisasi) yang teridentifikasi dengan jelas. Iklan tentang suatu destinasi atau paket perjalanan bisa dipasang di berbagai media elektronik maupun cetak. Iklan yang ingin memaksimalkan dramatisasi biasanya memilik media audio visual seperti televise (Cipto, 2018)

b) Pemasaran langsung yaitu penggunaan surat, telepon, faksimil atau internet yang dirancang untuk mengkomunikasikan secara langsung atau memastikan respons dan dialog dari wisatawan atau calon wisatawan tertentu (Saleng, 2018)

c) Pemasaran dari mulut ke mulut yaitu komunikasi lisan atau tertulis dari orang ke orang atau komunikasi elektronik yang berkaitan dengan hasil atau pengalaman mengunjungi suatu destinasi wisata, demikian yang dikemukakan oleh Matappa Wali sebagai berikut:"yang paling sederhana untuk memperkenalkan pantai lemo-lemo adalah dengan cara percakapan lewat mulut ke mulut, misalnya kita menrekomandasikan kepada orang yang sedangkan mencari tempat-tempat wisata bahari, pantai lemo- lemo adalah tempat salah satunya"(Wali, 2018).

Peran serta aktif dalam dilaksanakan secara langsung, baik secara erseranga maupun secara bersama-sama, yang secara sadar ikut membantu program pemerintah dengan inisiatif dan kreasi mau melibatkan diri dalam kegiatan pengusahaan pariwisatabahari atau melalui pembinaan rasa ikut memiliki dikalanan masyarakat.

\section{E. Dampak Objek Wisata Pantai Lemo- Lemo Dikabupaten Bulukumba}

a. Bidang Ekonomi

Pariwisata sebagai salah satu sektor strategis nasional, memang mempunyai efek ganda yang ditimbulkan oleh aktivitas pariwisata. Efek tersebut dapat bersifat langsung seperti penyerapan tenaga kerja, maupun yang bersifat tidak langsung seperti berkembangnya kegiatan ekonomi pendukung pariwisata seperti rumah makan, penginapan, penjual aneka souvenir dan oleh-oleh khas daerah tujuan wisata, transportasi, dan jasa pelayanan publik lainnya. Perekonomian masyarakat yang ada di sekitar Objek Wisata Pantai Lemo-Lemo, khususnya bagi mereka yang menfaatkan keberadaan objek wisata tersebut memilki relevansi terhadap peningakatan devisa yang dihasilkan oleh Objek Wisata Pantai Lemo-Lemo. Peningkatan jumlah pengunjung yang ada di Wisata Pantai Lemo-Lemo tentunya memberikan keuntungan bukan hanya kepada pemerintah Kabupaten Bulukumba, tapi juga kepada masyarakat yang ada disekitar Objek Wisata Pantai Lemo-Lemo.

Keberadaan Objek Wisata Pantai LemoLemo bagi mayarakat umum sangat mempengaruhi perekonomian mereka. Berikut ini adalah data yang mengambarkan meningkatnya perekonomian masyarakat dengan bukti fasilitas-fasilatas yang sifatnya 
sekunder telah mereka miliki sebagai implikasi terhadap keberadaan Objek Wisata Pantai Lemo-Lemo terhadap masyarakat sekitarnya khususnya mereka yang menjadi penjual aneka makanan dan minuman di Objek Wisata Pantai Lemo-Lemo, sampel dari tabel dibawah ini dalah sebanyak 20 penjual yang ada disekitar Objek Wisata Pantai Lemo-Lemo.

Penghasilan Objek Wisata Pantai LemoLemo setiap tahunnya mengalami peningkatan dengan selalu melampaui target pemcapaian devisa yang direncanakan. Hal ini membuktikan keberadaan Objek Wisata Pantai Lemo-Lemo sangat memberikan kontribusi bagi bagi PAD Kabupaten Bulukumba. target 2013 pencapaian melampuai target penghasilan diikuti tahuntahun berikutnya. Tahun 2014 adalah tahun dimana pencapaian yang melampui target memiliki angka tertinggi, target yang hanya Rp. 350.000.000 melampui hingga 500.000.000 (Saleng, 2018).

Pada saat sekarang ini berbagai usaha yang dilakukan oleh masyarakat untuk memanfaatkan keberadaan Objek Wisata Pantai Lemo-Lemo misalnya berjualan di sekitar tempat tersebut.Dengan hal tersebut, secara ekonomi keberadaan Objek Wisata Pantai Lemo-Lemo memberikan dampak bagi perekonomian masyarakat yang ada di sekitarnya.

\section{a. Sosial-Budaya}

Keberadaan Objek Wisata Pantai LemoLemo telah membawa dampak positif bagi masyarakat sekitarnya secara khusus dan masyarakat Kabupaten Bulukumba secara umum.Bagi masyarakat disekitarnya tentunya keberadaan Objek Wisata Pantai LemoLemo.

Dimanfaatkan sebagai lahan untuk mencari rezeki, selain dari pekerja kuli pembuat perahu juga sebagai petani .keberadaan Objek Wisata Pantai Lemo-Lemo secara umum menimbulkan dampak positif dan dampak negatif bagi masyarakat sekitar. berikut ini dampak positif yang ditimbulkan keberadaan Objek Wisata Pantai LemoLemo:

1) Munculnya lapangan kerja baru Masyarakat Kelurahan Tanah Lemo sebelum adanya Objek Wisata Pantai Lemo-Lemo mereka bekerja mayoritas sebagai petani, namun dengan adanya objek wisata tersebut mereka manfaatkan untuk mencari lapangan kerja meskipun tidak semua warga masayarakat bernasib sama dengan mendapatkan pekerjaan yang menjanjikan di lingkungan tersebut(Bahrun, 2018)

2) Meningkatnya kesejahteraan masyarakat Pembangunan objek wisata merupakan salah satu carayang dilakukan untuk menciptakan suatu perubahan di dalam kehidupan masyarakat. Tujuan dari adanya perubahan secara umum untuk menciptakan suatu kesejahteraan masyarakat.Hal ini terlihat pada masyarakat Tanah Lemo yang mengalami perubahan semenjak adanya perkembangan objek wisata pantai lemolemo.Objek wisata pantai lemo-lemo membawa dampak banyak bagi masyarakat sekitar.Salah satunya adalah terhadappeningkatan

pendapatan.Peningkatan pendapatan membawa dampak banyak bagi kehidupan masyarakat tanah lemo khususnya(Indahmeida, 2018).

3) Akses jalan menjadi lebih mudah Objek wisata juga memberikan dampak baik bagi pembangunan daerah Kelurahan Tanah Lemo, khusunya dalam akses jalan. Banyak warga masyarakat yang mengatakan bahwa sesudah adanya Obyek Wisata Pantai Lemo-Lemo memudahkan mereka untuk bepergian karena akses jalan yang dulunya belum bisa dilalui roda empat sekarang sudah bisa dan bahkan sudah di aspal(Bahrun, 2018). 
4) Membuat pola pikir masyarakat lebih maju Pola pikir masyarakat Kelurahan Tanah Lemo juga sudah lebih terlihat maju dibandingkan dulu sebelum adanya wisata pantai. Hal tersebut nampaknya juga dipengaruhi oleh faktor dari luar semenjak banyaknya wisatawan yang berkunjung ke Obyek Wisata Pantai Lemo-Lemo mereka menjadi lebih terbuka dan lebih maju pemikiranya (Tina, 2018).

\section{F. Kesimpulan}

Pantai Lemo-Lemo merupakan salah satu yang berada di Kecamatan Bonto Bahari, Kabupaten Bulukumba, yang terletak di ujung selatan pulau Sulawesi. Pengembangan pariwisata perlu diperhatikan sarana dan prasarananya karena sarana dan prasana mempengaruhi kualitas obyek dan respon wisatawan dalam hal kunjungan wisata. Pengembangan pariwisata merupakan bagian dari pembangunan wilayah, maka daerah yang berpotensi sebagai Daerah Tujuan Wisata (DTW) apabila dikembangkan nantinya akan membantu perekonomian daerah tersebut. pengunjung ke Objek Wisata Pantai LemoLemo di Kelurahan Tanah Lemo, Kecamatan Bonto Bahari, Kabupaten Bulukumba lima pada tahun 2004 terakhir :pengunjung objek wisata bahari khususnya Objek Wisata Pantai Lemo-Lemo hampir tiap tahun mengalami peningkatan baik dari pengunjung masyrakat setempat maupun dari masyarakat luar dari Kabupaten Bulukumba, pada tahun 2004 tabel menunjukkan bahwa jumlah pengunjung yang berkunjung ke Objek Wisata Pantai Lemo-Lemo sebanyak 11.502 orang. Pada tahun 2005 dan tahun 2006 jumlah pengunjung yang berkunjung ke Objek Wisata Pantai Lemo-Lemo sebanyak 12.034 (2005) orang dan 12.931 (2006) orang. Peran serta aktif dalam dilaksanakan secara langsung, baik secara erseranga maupun secara bersama-sama, yang secara sadar ikut membantu program pemerintah dengan inisiatif dan kreasi mau melibatkan diri dalam kegiatan pengusahaan pariwisatabahari atau melalui pembinaan rasa ikut memiliki dikalanan masyarakat. Dengan keberadaan objek wisata in sangat membawa damppak bagi masyyarakat setempat dan bagi pemerintah Kabupaten Bulukumba.

\section{DAFTAR PUSTAKA}

Andi, M. d. (2016 ). Pariwisata dan Perjalanan. Jakarta: Rajawali Pers.

antang, P. ( 2018), April Kamis). Sejarah Singkat Kerajaan Lemo-Lemo.

Antang, P. (2018, April Senin). Kelurahan Tanah Lemo.

Bagus, G. (2016). Geografi Pariwisata dan Ekonomi Kreatif. Jakarta: Rajawali Pers.

Bahrun. (2018, April Senin). Kelurahan Tanah Lemo.

BPS. (2015). Kecamatan Bonto Bahari dalam Angka 2015. Bulukumba.

bulukumba, D. P. (2015). Visi dan misi pariwisata bulukumba. Bulukumba.

Cipto, I. G. (2018, April Senin). (A. Agustina, Interviewer) Bulukumba.

Dr.H.Sulasman. (2010). Metodologi penelitian sejarah. Jakarta: Pustaka Setia.

Gunawan, I. (2018, April Senin). Bulukumba. Indahmeida, N. (2018, Maret Selasa). Bulukumba.

Indriwati. (2018, Apri Senin). Kelurahan Tanah Lemo.

Jamaluddin. (2015). Objek Pariwisata Mattampa 3013-2014. Makassar: UNM.

Pendit, N. S. (1986). Ilmu Pariwisata sebuah pengantar perdata. Jakarta: Pradnya Paramita.

Pendit, N. S. (1986). Ilmu Pariwisata sebuah pengantar perdata. Jakarta: Pradnya Paramita. 
PMD, K. (2015). Kecamatan Bonto Bahari 2015. Bulukumba.

Saleng, M. A. (2018, April Rabu). Bulukumba.

Sjamsuddin, H. (2012). Metodologi Sejarah. Yogyakarta: Penerbit Ombak.

Syukur. (2007). Objek Wisata Alam Lejja Dikabupaten Soppeng (1991-2002). Makassar: UNM.

Tina. (2018, April Minggu). Kelurahan Tanah Lemo.

Wali, M. ( 2018, April Selasa). Bulukumba. 